\title{
AN ANALYSIS OF SPEECH ACT IN ADVERTISING OF CHILD MILK ON TELEVISION
}

\author{
Fitri Novianti ${ }^{1}$, Regina Ratna Dewi Maliyani ${ }^{2}$ \\ ${ }^{1}$ IKIP Siliwangi, Cimahi, Indonesia \\ ${ }^{2}$ IKIP Siliwangi, Cicalengka, Indonesia \\ ${ }^{1}$ Fiitrinovianti@gmail.com, ${ }^{2}$ Reginardm123@gmail.com
}

\begin{abstract}
Making the advertisement is like we do communication with the others. In speech act, there are words include the meaning to convey the message to the viewers. The aim of this research is to describe the type of act of illocutionary and to analyze the most dominant illocutionary function produced in the advertising. This research is a descriptive research. The subject of this research is child milk advertising on television namely Bebelac 3, Nutrilon Royal 3, and Pediasure. The object of this research is a form of act illocutionary functions contained in advertising speech. Data acquisition uses note technique. Based on the analysis, the researchers get conclusion that the types of act illocutionary found in child milk advertising on television are declarative, representative, expressive, and commisive. In a child milk advertising on television, illocutionary function shows dominance representative and commisive. In the representative, this indicates the presence of a statement and affirmation. Moreover, in the commisives, this indicates the speaker give the promise to the viewers.
\end{abstract}

Keywords: Pragmatic, Speech act, Advertising

\section{INTRODUCTION}

The Introduction presents the purpose of the studies reported and their relationship to earlier work in the field. It should not be an extensive review of the literature. Use only those references required to provide the most salient background to allow the readers to understand and evaluate the purpose and results of the present study without referring to previous publications on the topic.

One of the way communicating with each other is called language. Language is device to communicating. In the study of language, what people do saying something is called speech act. This statement supported by Toolan in (Mudzakir 2013) Speech act refers to what is done when something is said. Thus, speech act is study of language by people saying something.

Advertising one of communication with the users of product service, advertisement are communications paid for those who send them and are planned to inform or influence people who receive the,. This is supported by Widyatama in (Fitriana 2010) adevertising means to obtain a strong position in competitive industrial circumsrtance. It typically attemps to persuade potential customers to purchase or to consume more of particular brand of product or services.

\section{Pragmatics}

According to $\mathrm{Li}$ (2016) pragmatics, as the study of language in use is a young science. Moreover, Leech (2016) states that "fifteen years ago, pragmatics was mentioned by linguistic rarely, if it all". 
From the definition above, it can be concluded that pragmatic is the system in which context supports to meaning.

In addition, Li (2016) said that pragmatic theories contain reference, deixis, anaphora, presupposition, speech act theory, indirect speech act theory, the cooperative principle and its maxim, conversational implicatures, the politeness principle and so on.

\section{Speech Act}

According to Austin in Isnawati (2015) that when people say or state something, they also do something or create an act, it is called speech acts. At this time, people can perform an action physically. The speakers do not need to do the action physically. The utterances said would be sufficient to perform an action.

From the definition above, the researchers get conclusion that speech act is study of the intention speaker meaning when people use the language performing an act.

According to Verceheren in Altikriti (2011) in performing speech acts, there are three related acts:

1) Locutionary act (or locution): the particular sense and reference of an utterance

2) Illocutionary act (or illocution): The act performed in, or by virtue of, the performance of the illocution; and

3) Perlocutionary act (or perlocution): The act performed by means of what is said

According to Searle in Dylgjeri (2017) illocutionary act into five, they are:

a. Directives, it is an attempt by speaker to get hearer to do something. The examples of directives are asking, begging, commanding, ordering, and requesting.

b. Commisives, speaker commits himself or herself to the performance of an action. The examples of commisives are offering, promising, swearing, threathening, and vowing.

c. Assertives, speaker represents a state of affairs. The utterances may be judgedtrue or false because they aim to describe a state of affairs in the world, for example affirming, reporting, informing, stating, and so on.

d. Expressives, speaker expresses a psychological state about the situation. The examples are welcoming, congratulating, thanking, etc.

e. Declaratives, the utterances attempt to change the world by representating it as having beeb changed, for example naming, sentencing, appointing, etc.

\section{Advertising}

According to Moriarty, et al (2015) advertising is any which is undertaken by or on behalf and advertiser or marketer for payment or other valuable consideration. Moreover, Raum (2014) stated advertising is a kind of communication. Its purpose is to inform people about a particular event, idea, or product. Most advertising is designed to sell products and services. Furthermore, according to Kottler in Fitriana (2010) "advertising is any paid form of nonpersonal communication of ideas, goods and service by an identify sponsor."

Based on O'Neill in Fitriana 2010) "language of advertising is apart from other languages". Moreover, Goshgarian in Fitriana 2010) defines that the power of advertisement is set up by two elements; image and words. These elements must be fully applied attentively since the combination of words and image makes up the language of advertising. The words and images used in making or creating advertisement will influence the reader's responses. To get expected effects or responses from the readers, an advertiser must be careful and smart in selecting and putting them. An advertisement not only provides information. 
From the definition above, the writers get conclusion that advertising is marketing and communicating which provides information of goods, ideas, and services. Advertising is also non-personal; it means that sellers and buyers are not face-to-face.

\section{METHOD}

Research design used in this study was descriptive qualitative method. This research was carried out by collecting the data, analyzing the data, presenting the result of data analysis. In collecting the data, the researchers used video recorder and transcrift. This technique was conducted by noting, categorizing, and classifying the data obtained. According to Searle (in Praditya et al, 2014) speech act can be classified into representative, directive, commissive, expressive, and declaration.

According to Praditya et al (2014) qualitative descriptive studies tend to draw from the general views of naturalistic inquiry. Based on Lincoln et al (in Praditya et al, 2014) "naturalistic inquiry implies only a commitment to studying something in its natural state or as it is to the extent that, this is possible in a research enterprise".

This study can be recognized as a pragmatics and also discourse analysis study since this study is related on the study of speaker's meaning and it needs to be analyzed as the study of discourse analysis using speech act theory. The focus of this study was to find the types of speech act, direct and indirect speech acts, and their classifications of types of speech acts, which can be formulated into representatives, directives, commisives, expressive, and declaration.

\section{RESULTS AND DISCUSSION}

\section{Results}

Based on the findings, there are five types of illocotuniory acts expressed by Searle. They are declarative, representative, expressive, directives, and commisive. The data is summarized in the table below:

Table 1

Nutrilon Royal 3 : Life is an Adventure

\begin{tabular}{cllc} 
No & \multicolumn{1}{c}{ Speech Act } & \multicolumn{1}{c}{ Clause } & Total \\
\hline 1. & Declarative & - & 0 \\
\hline 2. & Representative & $\begin{array}{l}\text { - And the answer to all my dream. } \\
\text { - You're my sun, my moon, my } \\
\text { guiding star. }\end{array}$ & 2 \\
& & $\begin{array}{l}\text { - My kind of wonderful, that's what } \\
\text { you are. }\end{array}$ & 1 \\
\hline 3. & Expressive & - & 0 \\
\hline 4. & Directives & - & 0
\end{tabular}


Table 2

Bebelac3 : medley You're My Everything

\begin{tabular}{|c|c|c|c|}
\hline No & Speech Act & Clause & Total \\
\hline 1. & Declarative & - To open my eyes, to be all I can be. & 1 \\
\hline 2. & Representative & $\begin{array}{l}\text { - To travel roads not taken, to meet } \\
\text { faces unknown. } \\
\text { - To feel the wind, to touch he stars. } \\
\text { - Life is adventure }\end{array}$ & 3 \\
\hline 3. & Expressive & - To stand tall with greatness. & 1 \\
\hline 4. & Directives & - & 0 \\
\hline & Commisive & $\begin{array}{l}\text { - I promise to discover myself. } \\
\text { - To chase down and catch every } \\
\text { dream. }\end{array}$ & 2 \\
\hline
\end{tabular}

Table 3

Pediasure : See Improvement in Growth

\begin{tabular}{cllc} 
No & \multicolumn{1}{c}{ Speech Act } & \multicolumn{1}{c}{ Clause } & Total \\
\hline 1. & Declarative & \multicolumn{1}{c}{0} \\
\hline 2. & Representative & $\begin{array}{l}\text { - That why pediasure has 25 key } \\
\text { nutrients. } \\
\text { - To support height weight, and natural } \\
\text { defense system. } \\
\text { - Complete nutrition from growth you } \\
\text { can be sorrow. }\end{array}$ & 3 \\
\hline 3. & Expressive & - She may not be eating well. & 1 \\
\hline 4. & Directives & \multicolumn{1}{c}{ - } & 0 \\
\hline 5. & Commisive & - And can become sickly. & 2 \\
& & - See improvement in growth. &
\end{tabular}

\section{Discussion}

After the researchers analyzed illocutionary act of child milk advertising on television such as Bebelac 3, Nutrilon Royal 3, and Pediasure, the researchers get types of illocutionary act.

Based on the Table 1 above, the researchers get 2 types of illocutionary act there are representative and expressive. In representative, we have two sentences. First, "And the answer to all my dream", this sentence has a meaning that he can find the way to make his dreams come true and this sentence gives the statement that the children can find their dreams. Second, "You're my sun, my moon, my guiding star", this sentence has a meaning that their mother is everything for them and to show they love with the lovely words. However, in expressive sentence that is "My kind of wonderful, that's what you are", it means the speaker give the expression of the sentence that his mother is more precious than anything.

Based on the Table 2 above, the researchers get 4 types of illocutionary act there are declarative, representative, expressive, and commisive. In declarative, we have "To open my eyes, to be all I can be", it means the speaker tell us they have an action that they can achieve their dreams. Whereas, in representative, we have 3 sentences. There are "To travel roads not 
taken, to meet faces unknown", "To feel the wind", and to touch the stars" and "Life is adventure", it means that three sentences above give the affirmation, description, and fact to viewers. Moreover, in expressive, that is "To stand tall with greatness", it means the speaker express the sentences that he able to reach out his dream easily. The last, is commisive we have two sentences. There are two sentences "I promise to discover myself" and "To chase down and catch every dream". It means the speaker give the promise that in the future, the promise they can be what they want to be, and they can find and get the way to make they dream be real.

Based on the table 3, we can see that we gets 3 types of illocutionary act, there are representative, expressive, and commisive. First, we have three sentences that include in representative there are "That whypediasure has 25 key nutrients", "To support height weight, and natural defense system", and "Complete nutrition from growth you can be sorrow". From the third statement that include representative about we can know that the pediasure have a lot of nutrients, to make our body ideal and also to make our body strong, so our body can fight the diseases, and microbe. Second, in expressive, we have a sentence "She may not be eating well", it means that the speaker give the statement that express if we do not drink pediasure may be the children not eating well. And the last part, we have two sentences in commisive. There are "And can become sickly", and "See improvement in growth". It means that if we did not drink that milk in the next may be our body will get sick, and if we have to drink that milk in the future our body can get the healthy.

\section{CONCLUSION}

In advertisement one, Bebelac 3: medley you are my everything that is the product extends the customer can make their children can reach his dream. After being analyzed, we can find the illocutionary acts of the advertisement are two representatives and one expressive.

In advertisement two, Nutrilon Royal 3: Life is an adventure, the song tell to the viewers that the child must know how the wild world. We can find one declarative, three representatives, one expressive, and two commisives.

In the last advertisement, Pediasure: see improvement in growth. This advertisement told that many benefits in that milk and can support the growth of the child. After being analyzed, we can find the illocutionary acts of the advertisement are three representatives, one expressive, and two commisives.

Thus, from the data above, not all the illocutionary act using in the advertisement but the most dominance illocutionary act used by the advertisement are representative and commisive.

\section{ACKNOWLEDGMENTS}

Alhamdulillahirabbil'alamin, praised be to Allah SWT., Lord of the world, who has given the writers His love and compassion to finish this journa entitled: An Analysis of Speech Act in Advertising of Child Milk on Television. This journal is a requirement for accomplishing S-1 degree in English Education Department, IKIP Siliwangi, Cimahi.

The writers greatest appreciation also goes to Dr. Irma Savitri Sadikin M, Pd as The Head of English Education Study Program. We also want to deliver my sincere thank to Yana, S.Pd as our adviser. Thank you for all your suggestions and guidance which are useful to finish our journal. We also thank to all lecturers in English Eduation Study Program for all your time to share your knowledge/Nothing is more important to us in pursuing this project than the 
members of our family. We would like to thank our parents for their endless love in giving us supports morally, motivation, and material support.

\section{REFERENCES}

Altikriti, S, F. (2011).Speech Act Analysis to Short Stories.Vol 2(6)

Advertising and Sales Promotion. (2014). Knowledge Flow

Fitriana, I. (2010). Speech-Act Analysis of XL Bebas Advertisements in Pulsa Tabloid.Vol 2(1).

Isnawati, et al. (2015).Speech Acts Analysis of the Main Character in Shrek Movie Script. Vol $1(3)$.

Lailiyah, S. (2015).Directive Speech Act of the Main Characters in Divergent Movie.Vol 5.

Li, Qiong. (2016). Studies in Second Language Learning and Teaching. SSLT 6 (4).

Moriarty, et all. (2015). Advertising Principles and Practice. Melbourne: Pearson Australia

Mudzakir, A. (2013). A Speech Act Analysis of Direct Utterances on Short Story Mr. Know All.

Praditya, et al. (2014).An Analysis of Speech Acts in the Conversation BetweenHabibie and Ainun in the Film Entitled Habibie and Ainun 2012. Vol 2

Raum, E.(2014). The Power of Advertising. London: Raintree

Rumaria, C. (2015). An Analysis of Speech Acts in the Dead Poets Society 